\title{
MANIFESTAÇÕES DO INVISÍVEL: A PLACA DE CARRO COMO UMA FORMA DE INDIVIDUALIZAÇÃO, NA CIDADE DE CURITIBA ${ }^{1}$.
}

\section{Tânia Bittencourt Bloomfield ${ }^{2}$}

A presente pesquisa qualitativa, inserida no âmbito da Geografia Cultural e no da Geografia das Representações, tem a intenção de mapear as motivações e perceber as relações que existem entre as visões de mundo, os contextos domésticos e profissionais, que levaram alguns dos proprietários de carros que circulam em Curitiba, a escolherem combinações de letras e números em suas placas, de modo a veicularem mensagens. Para dar conta da pesquisa de campo, está sendo utilizado o aporte teórico da Teoria das Representações Sociais em diálogo metodológico com a Etnometodologia e com a tríade de conceitos mundo percebido, mundo concebido e mundo vivido - propostos por Henri Lefébvre. Os conceitos de "lugar" e "território" concorrem como categorias analíticas, enquanto são desenvolvidas a sistematização e a análise das entrevistas, realizadas com trinta proprietários de veículos de Curitiba, cujas placas de carro foram escolhidas. Autores como Yi-fu Tuan, Werther Holzer, Rogério Haesbaert, Paulo César da Costa Gomes, Marcelo Lopes de Souza, entre outros, figuram como importantes fontes de referência. As placas escolhidas dos carros são os elementos que permitem ampliar o entendimento sobre a constituição do carro como um "lugar" e sobre as territorialidades envolvidas nas práticas que se dão, especialmente, nas ruas de Curitiba.

PALAVRAS-CHAVE: geografia cultural e das representações; placas escolhidas de carro; lugar; territorialidades.

\footnotetext{
${ }^{1}$ Orientadora: Profa. Dra. Salete Kozel Teixeira

2 Mestranda em Geografia (UFPR) - e-mail: taniabloomfield@gmail.com
} 